\title{
Research on High School Students' English Learning Anxiety
}

\author{
Jingjing Cui \\ Foreign Language Department, Dezhou University, Dezhou, China \\ Email: nathy1018@163.com
}

\begin{abstract}
In order to explore high school students' English learning anxiety in Chinese EFL (English as a Foreign Language) classrooms, this study surveyed and analyzed 105 students from a high school in Dezhou City, Shandong Province, China. The results indicated that students indeed had comparatively high anxiety in English learning. Males have higher anxiety of English classes than females. And it was also found that high anxiety plays a somewhat debilitative role in high school students' language learning, some suggestions for reducing students' anxiety in classrooms were proposed for teachers.
\end{abstract}

Index Terms—English learning anxiety, high school students, gender

\section{INTRODUCTION}

Considered to be an important affective variable, anxiety has been found to be correlated with English-learning achievement among different groups of people in various contexts. It has been observed that some students in English classrooms experience anxiety that results in stuttering and fast heart-beating. All of these phenomena are attributed to a psychological anxiety, which have been the research focus of many linguists and psychologists in recent years. Anxiety has been regarded as one of the most important affective factors that influence second language acquisition. Much research (e.g., Bailey, 1983; Horwitz, Horwitz \& Cope, 1986; Macintyre \& Gardner, 1994; Young, 1991), especially in western countries, has been conducted to find the relationship between anxiety and achievement in the learning of different foreign languages. Most studies (e.g., Horwitz, 1986; Macintyre \& Gardner, 1994) arrived at a conclusion that anxiety and achievement are negatively correlated. In China, similar research has also been conducted with different groups of people. Most of them, however, were college students. High school students, who are still at a comparatively low level of English proficiency and thus more easily experience a feeling of uneasy suspense (Rachman, 1998), are overlooked by most researchers. In this paper, the author endeavored to bridge this gap to find out the situation of this neglected group's English classroom anxiety through a study conducted in a key middle school of Shandong Province.

\section{LITERATURE REVIEW}

Anxiety, simply speaking, is a kind of troubled feeling in the mind. It is a subjective feeling of tension, apprehension, nervousness, and worry associated with an arousal of the automatic nervous system (Horwitz, 1986). Usually anxiety is classified into trait anxiety, state anxiety and situation-specific anxiety. Trait anxiety, as Scovel (1978) noted, refers to "a more permanent predisposition to be anxious" while state and situation-specific anxiety are usually experienced in relation to some particular event or situation (Brown, 2001). Language anxiety, the research target of this paper, belongs to the last category, which refers to the apprehension experienced when a situation requires the use of a second language with which the individual is not fully proficient (Gardner \& MacIntyre, 1993).

With the shifting of research focus from teachers to learners in SLA (Second Language Acquisition), affective factors, such as attitudes and motivation, were thought to account a lot for language learning outcomes. Anxiety, as a very important affective factor, has been considered very important, and many studies have been undertaken to explore it since the 1970s. The major concern of the earlier studies was the causes of language anxiety. According to Young (1991), there are six potential causes of language anxiety which include personal and interpersonal, learner beliefs about language learning, instructor beliefs about language teaching, instructor-learner interactions, classroom procedures and language tests. However, up to date, findings by Horwitz, Horwitz and Cope (1986) have been the most influential. They identified three causes of language anxiety, that is, communication apprehension, test anxiety and fear of negative evaluation.

When we explore the effect of anxiety on learning, an important insight to which we can refer is the distinction between debilitative and facilitative anxiety (Alpert and Haber, 1960). Up to now most studies have shown a negative relationship between anxiety and language achievement, that is to say, anxiety is a debilitator in language learning. Krashen (1985) once held in his affective filter hypothesis that high anxiety will prevent input that learners receive in the classroom from reaching the language acquisition device. Macintyre and Gardner (1994) based on a study of 97 college students that learn French, concluded that compared with more relaxed learners, those with anxiety find it more difficult to express their own views and tend to underestimate their own abilities. They also found that in the three 
stages of language acquisition, that is, input, processing and output, anxiety and learning achievement are negatively correlated. Moreover, there have also been some studies conducted to find the negative correlation between anxiety and four aspects of language learning, especially speaking and listening. In Zhang Baoyan's (1996) study of English learners in Taiwan, the results showed that there was no relationship between anxiety and learning achievement. So, from these studies it can be seen that the relationship between anxiety and achievement is probably not a simple linear one. It may be influenced by some other factors, such as culture and learners' proficiency. In mainland China, there have also been some studies conducted in the Chinese context to explore the relationship between anxiety and achievement (Lei, 2004; Tang, 2005; Wang, 2003; Xue, 2005). Most of them employed Horwitz's FLCAS (Foreign Language Classroom Anxiety Scale) and found a negative correlation. Going through these studies, it was found that the subjects participating in the studies were mostly college students. High school students who were at the critical stage of foreign language learning and may experience more anxiety in this process, however, were neglected. This study, therefore, was intended to examine the general situation of high school students' foreign language anxiety and the effects of anxiety on FL (Foreign Language) learning. As well, a comparison of male and female students' language anxiety was examined.

\section{METhODOLOGY}

\section{A. Subjects}

The subjects of the study were 105 second-year high school students (46 males and 59 females). They were from a science class and an art class of a high school in Dezhou City, Shandong Province. Their average age was 16 . They all had 5-8 years of experience of English learning.

\section{B. Instruments}

Two instruments were used for this study. They were a questionnaire assessing students' anxiety level and an achievement test. The questionnaire consists of two parts. One was intended to collect personal information of the participants, such as their name, age, gender, etc. The other was the Chinese version of FLCAS that was designed by Horwitz (1986). This questionnaire consists of 33 statements, of which 8 items were for communication anxiety (1, 9, $14,18,24,27,29,32), 9$ items for fear of negative evaluation $(3,7,13,15,20,23,25,31,33)$ and 5 items for test anxiety $(2,8,10,19,21)$. As for the remaining 11 items, they were put in a group which was named anxiety of English classes. The respondents were asked to rate each item on a five-point Likert scale ranging from 1 ("strong disagreement") to 5 ("strong agreement").

The test used to assess students' English achievement was the final exam administered at the end of the semester. The test paper included five parts: multiple choice, cloze, reading comprehension, error correction and writing, which were intended to assess students' overall ability in language use. All testing items were drawn from a test bank, which ensured the reliability of test paper.

\section{Data Collection}

The questionnaire was administered to 50 science students and 60 arts students. 110 copies were collected back and 105 replies were found statistically valid. Only the students from the science class supplied their English scores of the final exam.

\section{Data Analysis}

SPSS 13.0 was employed to analyze the data. Firstly, descriptive analysis was performed to compute the means and standard deviations for each item and each kind of anxiety to see the general situation of high school students' anxiety in English classrooms. Secondly, t-tests (t distribution tests) were employed to see if there were any differences in language anxiety between male students and female students. Then correlational analysis and t-tests were conducted to find out the effects of anxiety on English achievement.

\section{RESULTS \& FINDINGS}

\section{A. The General Situation of High School Students'Anxiety in English Classrooms}

The results of the descriptive analyses showed that there were 16 items whose means were above 3.00 . And of all the statements the 9th one had the highest index of 3.6571. The mean of the anxiety indices of all the subjects in English classrooms, as Table 1 shows, was 2.9309, which indicated that the high school students indeed had the feeling of anxiety in their English classrooms. Moreover, through the computation of means and standard deviations of each kind of anxiety, it was found that students' fear of negative evaluation, the mean of which reached 3.1831, was especially serious. Among the 16 items whose mean values were higher than 3.00 there were 7 statements concerning it, especially item 3, the mean of which was as high as 3.6579 . 
TABLE 1

THE OVERALL SITUATION OF HIGH SCHOOL STUDENTS' ANXIETY IN ENGLISH CLASSROOM

\begin{tabular}{|l|l|l|}
\hline Anxiety Variables & Mean & Standard Deviation \\
\hline Communication Apprehension & 2.8867 & .48557 \\
\hline Fear of Negative Evaluation & 3.1831 & .76055 \\
\hline Test Anxiety & 2.7734 & .71570 \\
\hline Anxiety of English Classes & 2.7415 & .66185 \\
\hline English Classroom Anxiety & 2.9309 & .60911 \\
\hline
\end{tabular}

\section{B. The Comparison of Males and Females' English Classroom Anxiety}

Table 2 shows that in terms of either the general English classroom anxiety or each specific kind of anxiety, males' means were always higher than females, which indicated that males may experience more anxiety than females in English classrooms. But the results of t-tests (Table 3) showed that there were no significant differences between males and females in most anxiety variables except that of English classes $(\mathrm{p}=0.026<0.05)$.

TABLE 2

MALES AND FEMALES' ENGLISH CLASSROOM ANXIETY

\begin{tabular}{|l|l|l|l|}
\hline \multicolumn{4}{|c}{ MALES AND FEMALES'ENGLISH CLASSROOM ANXIETY } \\
\hline Anxiety Variables & Gender & Mean & Standard Deviation \\
\hline \multirow{2}{*}{ Apprehension } & Male & 3.1897 & .61061 \\
\cline { 2 - 4 } & Female & 3.0383 & .66748 \\
\hline \multirow{2}{*}{ Fest Anxiety } & Male & 3.2134 & .83637 \\
\cline { 2 - 4 } & Female & 3.1539 & .68776 \\
\hline \multirow{2}{*}{ Anxiety of English Classes } & Male & 2.9053 & .69587 \\
\cline { 2 - 4 } & Female & 2.6510 & .71784 \\
\hline \multirow{2}{*}{ English Classroom Anxiety } & Male & 2.8836 & .65992 \\
\cline { 2 - 4 } & Female & 2.6059 & .64037 \\
\cline { 2 - 4 } & Male & 3.0115 & .62022 \\
\cline { 2 - 4 } & Female & .59556 \\
\hline
\end{tabular}

TABLE 3

THE COMPARISON OF MALES AND FEMALES

\begin{tabular}{|l|l|l|}
\hline Anxiety Variables & $\mathrm{t}$-value & Significance of t-value $(\mathrm{p}<0.05)$ \\
\hline Communication Apprehension & 1.219 & 0.225 \\
\hline Fear of Negative Evaluation & 0.403 & 0.685 \\
\hline Test Anxiety & 1.917 & 0.057 \\
\hline Anxiety of English Classes & 2.245 & $0.026^{*}$ \\
\hline English Classroom Anxiety & 1.248 & 0.216 \\
\hline
\end{tabular}

\section{The Relationship between Anxiety and English Achievements}

The results of the correlation analysis indicated that anxiety and English achievement were only correlated in terms of test anxiety. And they were negatively correlated $(-.277, \mathrm{p}=0.039<0.05)$. It was noted that the coefficient of anxiety for English classes was -0.232 which approached the significant level of -0.25 . Therefore, the students from the science class were divided into two groups according to their English scores in the final exam. A t-test was then employed to see if there were any significant differences in the anxiety of English classes between these two groups. The results of the analysis supported the hypothesis that was proposed above. It was found that anxiety of English classes indeed affects high school students' English achievement $(\mathrm{p}=0.037<0.05)$.

TABLE 4

THE CORRELATION OF ANXIETY AND ENGLISH ACHIEVEMENT

\begin{tabular}{|l|l|l|}
\hline Anxiety Variables & Correlation Coefficient & p-value $(<0.05)$ \\
\hline Communication Apprehension & -.101 & 0.456 \\
\hline Fear of Negative Evaluation & -.097 & 0.475 \\
\hline Test Anxiety & $-.275^{*}$ & 0.037 \\
\hline Anxiety of English Classes & -.230 & 0.083 \\
\hline English Classroom Anxiety & -.225 & 0.102 \\
\hline
\end{tabular}

\section{DISCUSSION}

\section{A. The Existence of Language Anxiety in English Classrooms}

Similar to the findings of Tang's study (2005) among college students, this study indicated high school students indeed had the feeling of anxiety in their English classrooms. And they experienced more fear of negative evaluation. The reasons for such results can be explored from two aspects. One aspect is closely related with high school students themselves. The other mainly deals with some external factors. In the aspect of students themselves, the existence of anxiety should firstly be attributed to their English proficiency, which was not high enough to allow them to communicate with others freely, express themselves adequately in class and answer teachers' questions properly. So, in 
English classrooms where much communication is needed, high school students are more anxious than in other classes. Secondly, it is the cultural tradition that Chinese people care much about their faces, so they don't like to receive low evaluations or criticism about themselves. This is the reason why they experienced more fear of negative evaluation than any other kind of anxiety. Moreover, during high school, the stress of the national examination for college entrance and the serious competition among students also causes some students to pay more attention to others' strong points and their own weak points, which results in the arousal of anxiety. As for the external factors, the reasons should first come from the large context of English learning in China. Research has indicated that contact with the people and culture of the target language could reduce anxiety (Tang, 2005). However, although China has become more and more open to the world, and many foreigners have come to China in the past thirty years, most English learners, especially high school students, seldom have opportunities to communicate with native speakers of English. Thus, high school students tend to experience more anxiety in English classrooms. Moreover, most Chinese teachers in middle schools overwhelmingly emphasize reading and writing, while paying less attention to listening and speaking. The existence of anxiety in English classrooms can also be ascribed to classroom atmosphere (Wang, 2003). In most Chinese EFL classrooms, teachers play the role of controller or dominator. Students usually feel nervous or oppressed. Consequently, they lack a free, relaxed environment for English learning. Finally, another factor that cannot be overlooked is the high expectations of Chinese parents for their children. Such high expectations usually do not encourage students, but often result in more anxiety.

\section{B. Males Have More Anxiety of English Classes than Females}

In general, females are thought to be more adept in language learning than males. Female students usually score higher than male students in English exams. Therefore, it is not hard to imagine that females are more confident in their abilities to learn a new language well. Once they gain faith in their capabilities, they will be more ready to "approach threatening situations" (Dörnyei, 2001) in English classrooms. On the contrary, males, who have higher frequency of language learning failure, are inclined to attribute their bad performance in English classes to their low ability. Consequently, they are more anxious about English classes. However, as English is a compulsory testing subject of the college entrance exam in China, students all exert themselves to study it. Though males show less aptitude for English than females, great effort helps to make up a lot for it. Moreover, now in English classes teachers try to provide equal opportunities to students. More experience of English use will reduce their anxiety about it. Therefore, generally the gap between males and females is not very large now. In many English tests the highest scores were attained by some male students. That is the reason why no significant differences were found between them, though males' means were a little higher than females.

\section{Anxiety Plays a Debilitative Role in Language Learning}

According to the results of the study, test anxiety and anxiety of English classes were significantly correlated with high school students' English achievement. In terms of the other factors, although the relationship was insignificant, the coefficients were all negative. Thus, it can be said that anxiety plays somewhat a debilitative role in language learning.

Actually, the finding of the negative role of anxiety has been noted in many previous studies, e.g., Horwitz (1986), MacIntyre and Gardner (1994), Tang (2005). Usually, high anxiety can make learners get discouraged, lose faith in their abilities, escape from participating in classroom activities, and even give up the effort to learn a language well. Therefore, the learners with high anxiety often get low achievement. And low achievement makes them more anxious about learning.

Another notable finding of the study was the significant correlation between English achievement and test anxiety, anxiety of English classes. In China, high school students usually spend most of their time on English learning in classrooms. Each student usually has 6-8 English classes each week. Moreover, compared with college students, they usually take more English tests. A high school student usually takes a test every three units. And in each term they at least have two large-scale exams - a mid-term exam and a final. Therefore, some students with poor English achievement were anxious about, or even discouraged by English classes and tests.

\section{CONCLUSION}

This paper has presented some findings of high school students' anxiety in Chinese EFL classroom. It was found that most students experienced anxiety in classrooms, especially the fear of negative evaluation. Male students were found to have higher anxiety of English classes than females. Moreover, it also found that anxiety is a debilitator in language learning, especially anxiety of tests and English classes.

Given the situation that anxiety is prevalent in Chinese high school English classrooms; teachers must pay more attention to it. Besides preparing properly for teaching, teachers should take the affective factors of students into consideration (Zhang \& Chang, 2004). First of all, they can try to create a relaxed atmosphere for students, which can make them feel safe to speak or express their views. Secondly, teachers should avoid negative evaluation of students in classrooms and comment on students' behaviors with more encouragement. Thirdly, teachers, together with our schools, should take some measures to relax students' attention on exams, such as eliminating the ranking of students by their test scores. Finally, teachers can also explicitly tell students the inevitability of the existence of anxiety in English 
learning and let them know that anxiety can be reduced through the self-regulation of their thinking and study. Although teachers can make use of the above-mentioned means to help students to overcome their anxiety in English classrooms, teachers should not try to help students get away from anxiety completely. Much research indicates that adequate anxiety plays a positive role and can motivate students to maintain their efforts on learning. Therefore, the teachers' real job is to help students keep adequate anxiety, neither too high nor too low. As the study was only conducted in one school, more research is needed to support the findings and to find more about high school students' anxiety in English classrooms.

\section{APPENDIX}

English version of FLCAS (Foreign Language Classroom Anxiety Scale)

1. I never feel quite sure of myself when I am speaking in my foreign language class.

2. I don't worry about making mistakes in language class.

3. I tremble when I know that I'm going to be called on in language class.

4. It frightens me when I don't understand what the teacher is saying in the foreign language.

5. It wouldn't bother me at all to take more foreign language classes.

6. During language class, I find myself thinking about things that have nothing to do with the course.

7. I keep thinking that the other students are better at languages than I am.

8. I am usually at ease during tests in my language class.

9. I start to panic when I have to speak without preparation in language class.

10. I worry about the consequences of failing my foreign language class.

11. I don't understand why some people get so upset over foreign language classes.

12. In language class, I can get so nervous when I forget things I know.

13. It embarrasses me to volunteer answers in my language class.

14. It would not be nervous speaking in the foreign language with native speakers.

15. I get upset when I don't understand what the teacher is correcting.

16. Even if I am well prepared for language class, I feel anxious about it.

17. I often feel like not going to my language class.

18. I feel confident when I speak in foreign language class.

19. I am afraid that my language teacher is ready to correct every mistake I make.

20. I can feel my heart pounding when I'm going to be called on in language class.

21 . The more I study for a language test, the more confused I get.

22 . I don't feel pressure to prepare very well for language class.

23. I always feel that the other students speak the language better than I do.

24. I feel very self-conscious about speaking the foreign language in front of other students.

25. Language class move so quickly I worry about getting left behind.

26. I feel more tense and nervous in my language class than in my other classes.

27. I get nervous and confused when I am speaking in my language class.

28 . When I'm on my way to language class, I feel very sure and relaxed.

29. I get nervous when I don't understand every word the language teacher says.

30. I feel overwhelmed by the number of rules you have to learn to speak a foreign language.

31. I am afraid that the other students will laugh at me when I speak the foreign language.

32. I would probably feel comfortable around native speakers of the foreign language.

33. I get nervous when the language teacher asks questions which I haven’t prepared in advance.

\section{REFERENCES}

[1] Alpert, R. \& R. Haber. (1960). Anxiety in academic achievement situations. Journal of Abnormal and Social Psychology, 61, 207-215.

[2] Bailey, K. (1983). Competitiveness and anxiety in adult second language leaning: Looking at and through the diary studies. In H. Seliger and M. Long (Eds.), Classroom-oriented research in second language acquisition (pp. 67-102). Rowley: Mass Newbury House.

[3] Brown, H. D. (2001). Principles of language learning and teaching. Beijing: Foreign Language Teaching and Research Press, 141-142.

[4] Dörnyei, Z. (2001). Teaching and researching motivation. London: Longman.

[5] Horwitz, E., M. Horwitz \& J. Cope. (1986). Foreign language classroom anxiety. Modern Language Journal, 70, 125-32.

[6] Krashen, S. (1985). The Input Hypothesis. London: Longman.

[7] Lei Xiao. (2004), Survey on undergraduates' English learning anxiety in class and implications on English teaching. Foreign Languages and Literatures 79, 46-51

[8] MacIntyre, P. D. \& R. C. Gardner. (1991). Methods and results in the study of anxiety and language learning: A review of the literature. Language Learning, 41, 85-117.

[9] MacIntyre, P. D. \& R. C. Gardner. (1994). The subtle effects of language anxiety on cognitive processing in the second language. Language Learning, 44, 283-305. 
[10] Rachman, S. (1998). Anxiety, Hove, East Sussex. UK: Psychology Press.

[11] Scovel, T. (1978). The effect of affect on foreign language learning: a review of the anxiety research. Language Learning, 28, 128-142.

[12] Tang Meiling. (2005).Survey and study of non-English major undergraduates' English learning anxiety in class. Taituan Normal University Journal (social science edition) 4, 145-146

[13] Wang Qi. (2003). A relative study of foreign language learning anxiety and classroom atmosphere and its teaching significance. Northwest Normal University Journal (social science edition) 6, 27-31

[14] Xue Lifang. (2005). A relative study of English learning anxiety and English achievement. Shan Xi Agricultural University Journal (social science edition) 4, 246-248.

[15] Young, D. J. (1991). Creating a low-anxiety classroom environment: What does language anxiety research suggest? Modern Language Journal, 75, 426-439.

[16] Zhang Baoyan (1996). Research on Chinese students' English learning anxiety Teaching and research (Tai Bei) 18, 45-68.

Jingjing Cui was born in Dezhou, China in 1977. She received her M.A. degree in linguistics from Shan dong University, China in 2005.

She is currently a lecturer in the School of Foreign Languages, Dezhou University, Dezhou, China. Her research interests include language teaching and translation. 